Rev. Mus. Argentino Cienc. Nat., n.s.

1(2): $121-127,1999$

\title{
Chiloscyphus subgenus Phaeochiloscyphus (Hepatophyta, Geocalycaceae) from southern South America
}

\author{
Gabriela G. HÄSSEL de MENÉNDEZ
}

\begin{abstract}
Museo Argentino de Ciencias Naturales "Bernardino Rivadavia", Av. A. Gallardo 470, 1405 Buenos Aires, Argentina.
\end{abstract}

\begin{abstract}
Chiloscyphus subgenus Phaeochiloscyphus J. J. Engel \& R. M. Schust. is revised and shown to contain two species, C. durus (Steph.) Hässel, comb. nov. and C. magellanicus Steph. Study of additional material has shown that Chiloscyphus hookeri J.J. Engel must be treated as a new synonym of C. durus, as is Leptoscyphus decipiens Mitt, nom. inval. Chiloscyphus lobatus Steph. is treated as a new synonym of C. magellanicus. The two accepted species are distinguished by a key; typification and synonymy are presented in full and all specimens studied from Chile and Argentina are cited along with a summary of distribution and ecology. Finally, $C$. magellanicus is fully described and illustrated for the first time.
\end{abstract}

尴ey words: Hepaticopsida, Liverwort, Geocalycaceae, taxonomy, Chile, Argentina.

Resumen: Al revisar Chiloscyphus subgénero Phaeochiloscyphus J.J. Engel \& R.M. Schust. se demuestra que contiene dos especies, $C$, durus (Steph.) Hässel comb. nov. y C. magellanicus Steph. El estudio de material adicional reveló que Chiloscyphus hookeri J.J. Engel debe ser tratado como nuevo sinónimo de C. durus, como así también Leptoscyphus decipiens Mitt. nom. inval. Chiloscyphus lobatus es considerado nuevo sinónimo de C. magellanicus. Se distinguen las dos especies a través de una clave; tipificaciones y sinonimia se presentan en detalle y se citan todos los ejemplares estudiados de Chile y Argentina con un resumen de distribución y ecología. Además por primera vez se describe en detalle y se ilustra $C$. magellanicus.

Chiloscyphus subgenus Phaeochiloscyphus J. J. Engel \& R. M. Schust., was established by Engel \& Schuster (1984) to include Chiloscyphus hookeri J. J. Engel and its two varieties. This is an easily distinguishable taxon, reported by Engel (1972:150) from Chile (Magallanes, Desolación I., Newton I., and B. Tekenika) and from Argentina (Tierra del Fuego and Malvinas Is.), and reported by the same author (1978:152) from the Brunswick Peninsula and (1990:115) from Malvinas Is. The correct name of this taxon is C. durus (Steph.) Hässel because its basionym Lophocolea dura Steph, has priority over $C$. hookeri J. J. Engel, a name slipped before into the synonymy of "Leptoscyphus expansus" (Grolle, 1962: 62).

Chiloscyphus magellanicus Steph. was placed by Engel \& Schuster (1984: 400) in the genus Heteroscyphus Schiffn. The first defining character of this genus -"the androecia are consistently on abbreviated spicate intercalary branches, that totally lack normal vegetative leaves"- as indicated by Engel \& Schuster (1984: 400 ), is not displayed by this particular species, as shown in the description and illustration presented below (Fig. 2.1).

The purpose of this study is to reinstate the name Chiloscyphus magellanicus Steph. in Chiloscyphus Corda to which it truly belongs, and to add a new synonym, which had been wrongly placed in synonymy in another genus. Chiloscyphus magellanicus should also be included in subgenus Phaeochiloscyphus because it shares some characters with C. hookeri J. J. Engel, a taxon which must now be called $C$. durus (Steph.) Hässel.

Chiloscyphus subgenus Phaeochiloscyphus J. J. Engel \& R. M. Schust., Nova Hedwigia 39: $409,1984$.

Plants brown; leaves ovate, convex, entire, occasional basal distal teeth present, or bifid leaves on the same plant; antheridia stalks 2seriate; gynoecia most frequently borne on short lateral intercalary branches; perianth originally trigonous, cylindric, campanulate to cupulate, mouth wide, broadly dentate to laciniate. Sporophyte only known from C. durus (Steph.) Hässel [Engel (1972:152 under C. hookeri J. J. Engel)]. No asexual reproduction known.

Type species: Chiloscyphus hookeri J. J. Engel 
At present two taxa belong to this subgenus:

1) Plants robust, light green to light brown; stem 18-20 cells wide; leaves alternate, dor sal margin flat, dorsal stem middle line (free of leaves) up to 8 cells wide; central leaf cells 47-70 $\times 35-47 \mu \mathrm{m}$ in diam.; cell walls thin, trigones small; amphigastria connate on one side to one leaf; perianth obscurely trigonous at apex, ventral portion infolded, mouth with \pm 40 laciniae all around, lateral portions obscurely bifid with additional straight to curved, elongated, unequal laciniae, at their base $2-4$ cells wide, apex a uniseriate filament $3-9$ cells long.

Chiloscyphus durus (Steph.) Hässel

2) Plants delicate, when dry brown or red brown; stem (6)-16 cells in diam.; leaves subopposite, dorsal margin slightly recurved, dorsal stem middle line (free of leaves) $2(-3)$ cells wide; central leaf cells 51-80 x 44-61 $\mu \mathrm{m}$ in diam., cells walls thickened on dorsal surface, trigones conspicuous; amphigastria connate on both sides to leaves; perianth cupulate, mouth wide, with \pm 16 laciniae all around, lateral portions obscurely bisbifid with additional laciniae, each lacinia triangular elongated curved, at their base $4-10$ cells wide, apex a uniseriate filament $4-10$ cells long

Chiloscyphus magellanicus Steph.

Chiloscyphus durus (Steph.) Hässel comb. nov.

ELophocolea dura Steph., Kongl. Svenska Vetenskapsakad. Handl. 46(9): 43, fig. 16 a-d, 1911 ; basionym. Typus: Chile, Patagonia Austr., Canal Gajardo, Strandfelsen am Inga Gletscher, Skottsberg 1908 [G 17780 holotypus of Lophocolea dura Steph. (Grolle 1962: 65) S, UPS isotypi].

$=$ Leptoscyphus decipiens Mitt. nom. nud., London J. Bot. 3: 358 , 1851. syn. nov. Original material: Cape Horn, Dr. Hooker (NY as Leptoscyphus chiloscyphoides with Lophocolea pallidovirens Taylor)

= Chiloseyphus hookeri J. J. Engel, J. Hattori Bot. Lab. 36: 150. Figs. 1(1-6); 2(1-10), 1972, syn. nov. Typus: Chile, Magellanes, I. Hermite, Hooker 12, p. p. (NY holotypus, mixed with Jungermannia pallidovirens Hook.f. \& Taylor; BM, G isotypi).

= Chiloscyphus hookeri var constantifolius J. J. Engel, J. Hattori Bot. Lab. 36: 155, 1972. Typus: Chile, Tierra del Fuego, Bahía Tekenika, C. Skottsberg ser. III, $\mathrm{n}^{0} 33$ as Leioscyphus horizontalis (Hook.) Steph. (S-PA holotypus).

\section{Description}

This species has been well-described and illustrated by Engel (1972: 150) under Chiloscyphus hookeri J. J. Engel.

\section{Discussion}

In the diagnosis of the subgenus Phaeochiloscyphus J. J. Engel \& R. M. Schust. (Engel \& Schuster, 1984) it is indicated that the small lateral intercalary branches, bearing perianths, are devoid of leaves. This is incorrect, as in $C$. durus (Steph.) Hässel, (including C. hookeri J. $J$. Engel, the type species of this subgenus), these branches can be longer and are nearly all provided with leaves.

Lophocolea dura Steph. was placed by Grolle (1962: 62) in the synonymy of "Leptoscyphus expansus (Lehm.) Grolle". This placement was accepted by Engel (1978: 179) and Engel and Schuster (1984: 428). The type of Lophocolea dura Steph. consists of dark brown (in the dry condition) female plants. The leaves are entire or occasionally have one basal distal tooth, are recurved ventrally and aithough quite imbricate leave dorsally a conspicuous middle line along the stem free of leaves; the leaf cells have small trigones. The amphigastria, with 2 divergent principal segments, have lateral teeth on the lamina sides. Several young perianths are present on short leafy branches, (with $2-3$ cym cles of leaves under the bracts). The young perianths, $2-3 \mathrm{~mm}$ high, have a trigonous structure with pronounced dorsal and ventral-lateral keels, the ventral smaller portion is infolded, the mouth is 3-lobate and dentate, these teeth are triangular-acuminate, at their base 24 cells wide. These specimens are reminiscent of $C$. magellanicus Steph., but the perianth form and teeth are quite different, as in the latter one the perianth mouth has conspicuous lacinia, rather than teeth.

Specimens from Peninsula Brunswick, Cabo San Isidro collected by Roivainen 2395 (at H), determined first by S. Arnell as Lophocolea pallidovirens, then later by Engel (1978: 152) as Chiloscyphus hookeri var. constantifolius J. J. Engel, belong to Leptoscyphus, while Roivainen $2401(\mathrm{H})$ identified by Engel (1.c.) as Chiloscyphus hookeri var. constantifolius, contains three species: Leptoscyphus sp. (c. per.), Leptoscyphus chiloscyphoides (c. per.) and Chiloscyphus durus (masc., c. per.).

The holotype of C. hookeri var. constantifolius J. J. Engel (at S.PA) consists of female plants which have long stems, with entire leaves, which sometimes alternate with leaves with one basal tooth, one of the characters that defines the species; this situation is most common and therefore it is not necessary to maintain the name of the variety as it cannot be distinguished from the type variety. 


\section{Specimens examined.}

CHILE: Chiloé, Cordillera de Piuchué. Alerzal 500 m.s.m., Villagrán 15 , id 22 (VILLAGRAN ${ }^{1}$ ). Baie de L' Isthme, Savatier 207 (VER as Lophocolea pallidovirens). Cana? Gajardo, Caleta Inga, Skottsberg 1908 (c. per.) (c) 17780 holotypus of Lophocolea dura Steph. \$, UPS, isotypi). Ancón Sin Salida, Seno Unión, G.H.M." TBPA-B 655 ; id 656; id 820. Piazzi I., Caleta Ocasión, G.H.M. TBPA-B 914a; id 1118. Vidal Gormaz I., G.H.M. TBPA-B 1590. Pto. Bellavista, Lago Azul, Schiavone TBPA-B 2086; id 2092; id 2096 (c. per); Pto. Bellavista, Cerro Morro, Schiavone TBPA-B 2182; id 2207; id $2294 a$; id 2299 (masc. c. per.); Pto. Toro, Río Serrano, Schiavone TBPA-B 2495 (masc. c. per); Pto. Toro, al pié del Cerro Balmaceda, Schiavone TBPA-B 2558b. Savatier 1782 (VER as Chiloscyphus pallidovirens?). York Bay, Lechler 1362 (NY with Chiloscyphus pallidovirens). Chatham I., Engel 5358A p.p. (MSC). Newton I., Dusen 95 (M, S). Brunswick Península, B. San Nicolás, Engel 6360 p. p. (MSC). Riesco 1., C.A. y G.H.M. 433. Desolación, Pto. Angosto, Dusen 385 (BA 30583). Tierra del Fuego, Halle (NY as Chiloscyphus amphibolius); id, Furia I., Hyvönen 2975a-b (NY). Sarmiento Bay, Spegazzini 273(4) (VER as Chiloscyphus grandifolius); id 240 (VER as Chiloscyphus surrepens). Hoste I., Hyades (VER as Chiloscyphus pallidovirens ?); id, Hariot 170 (VER as Chiloscyphus pallidovirens?); id Hahn 130 (VER as Chiloscyphus pallidovirens ?). Basket I., Darwin Sound, Spegazzini 177 (VER as Chiloscyphus grandifolius); id 218 p. p. (VER as Chiloscyphus grandifolius). Wollaston I., Hariot 90 (VER as Leioscyphus chiloscyphoides var. major ?). Hermite I., Hooker 12 p. p. INY holotypus of Chiloscyphus hookeri J. J. Engel, with Jungermannia pallidovirens Hook.f. \& Taylor BM (c. per), G isotypi]. Cape Horn, Dr. Hooker (NY original material of Leptoscyphus decipiens Mitt.); id, (NY with C. magellanicus Steph.). Rennell I., matorral costero, Eskuche 70-26 (CTEFN); id, Bahía Tekenika, C. Skottsberg ser.III, $\mathrm{n}^{\circ} 33$ [S-PA as Leioscyphus horizontalis (Hook.) Steph.]. ARGENTINA. Tierra del Fuego, Paso Garibaldi, G.H.M. e I. Gamundi 1477. Destacamento Lago Cami, C.A. y G.H.M. 907. Lago Escondido, Solari 11 (BA 22212c); id G.H.M. 3550 . Valle Carbajal, G.H.M. 2438; id 3269. Lapataia, G.H.M. 2482. Bahía San Valentin, G.H.M. 3809 (c. per. c. caps.). Bahía

\footnotetext{
${ }^{1}$ Field record collection

${ }^{3}$ G.H.M. $=$ G. Hässel de Menéndez in Hb. BA

${ }^{3}$ TBPA-B $=$ Transecka Botánica de la Patagonia AustralBriofitas
}

Slogget, Spegazzini (c. per.) (VER). Península Mitre, Cerro Arriola, Hyvönen 3095 (BA). Isla de los Estados (Staten 1.) Bahía Crossley, G.H.M. 3866; id 3885 (masc.); id 3880 (c. per. c. caps). Bahía Flinders, G.H.M. 4563 (c. per. c. caps); id 4611 (c. per). Pto. Cook, G.H.M. 3018 (masc.); id Spegazzini 14(a) (VER as Lophocolea pallidovirens); id 38 (1) (VER as Chiloscyphus grandifolius); id 40 (VER as Leioscyphus chiloscyphoides). Pto. Roca, Castellanos (BA 1414); id G.H.M. 4003 (c. per.). Mte. Conegliano, Spegazzini 43 (VER as Chiloscyphus grandifolius). Monte Italia, Spegazzini 110(VER as Chiloscyphus grandifolius). Pto. San Juan, G.H.M. 4132, id 4204; id Castellanos (BA 1398), id (BA 1413). Pto. Vancouver G.H.M. 3107; id 4315 (c. per). Observatorio 1., G.H.M. 3923; id 3931. Goffré 1., G.H.M. 3955. Barbagallo, (masc. c. per.) (BA 15266). Maivinas I. Charcot Expedition (M); Pto. Stanley, Skottsberg (S as Lophocolea pallidovirens).

\section{Ecology and distribution}

Engel (1978: 152) described the ecology of $C$. hookeri, in the Brunswick Peninsula and in the Malvinas I. (Engel, 1990: 115).

Chiloscyphus durus turns out to be very widely distributed in the evergreen forest zone reaching from Chiloe $I$. in the north, as far as to the eastern tip of southern South America, the Isla de los Estados; where it has been found with perianths and sporophytes. A detailed observation even of sterile specimens, allows identification of the taxon, nevertheless it was in the past overlooked and confused with other taxa (see list of specimens examined). It grows loosely in the hepatic carpet that covers the ground, also on stream banks under Gunnera sp., on rotten logs and in the coastal shrub fringe, with Gackstroemia magellanica (Lam.) Trev., Blepharidophyllum densifolium (Hook.) Angstr., Telaranea plumulosa (Lehm, \& Lindenb.) Fulf., Chiloscyphus obvolutus (Hook.f. \& Taylor) Hässel, C. pallidovirens (Hook.f. \& Taylor) Taylor, C. magellanicus Steph. and other common hepatics.

Chiloscyphus magellanicus Steph., Spec. Hep. 3: 256, 1908.

Figs. 1-2

$\equiv$ Heteroscyphus magellanicus (Steph.) J. J. Engel \& R. M. Schust., Nova Hedwigia 39: 400, 1984; syn. nov. Typus: Patagonia occidentalis, Dusen 373 [FH lectotypus (Engel, Fieldiana 41: 154, 1978)]; Fretum Magellanicum, Smyth Channel (Cr syntypus).

=Chiloscyphus lobatus Steph., Spec. Hep. 3:256, 1908; syn. nov. 


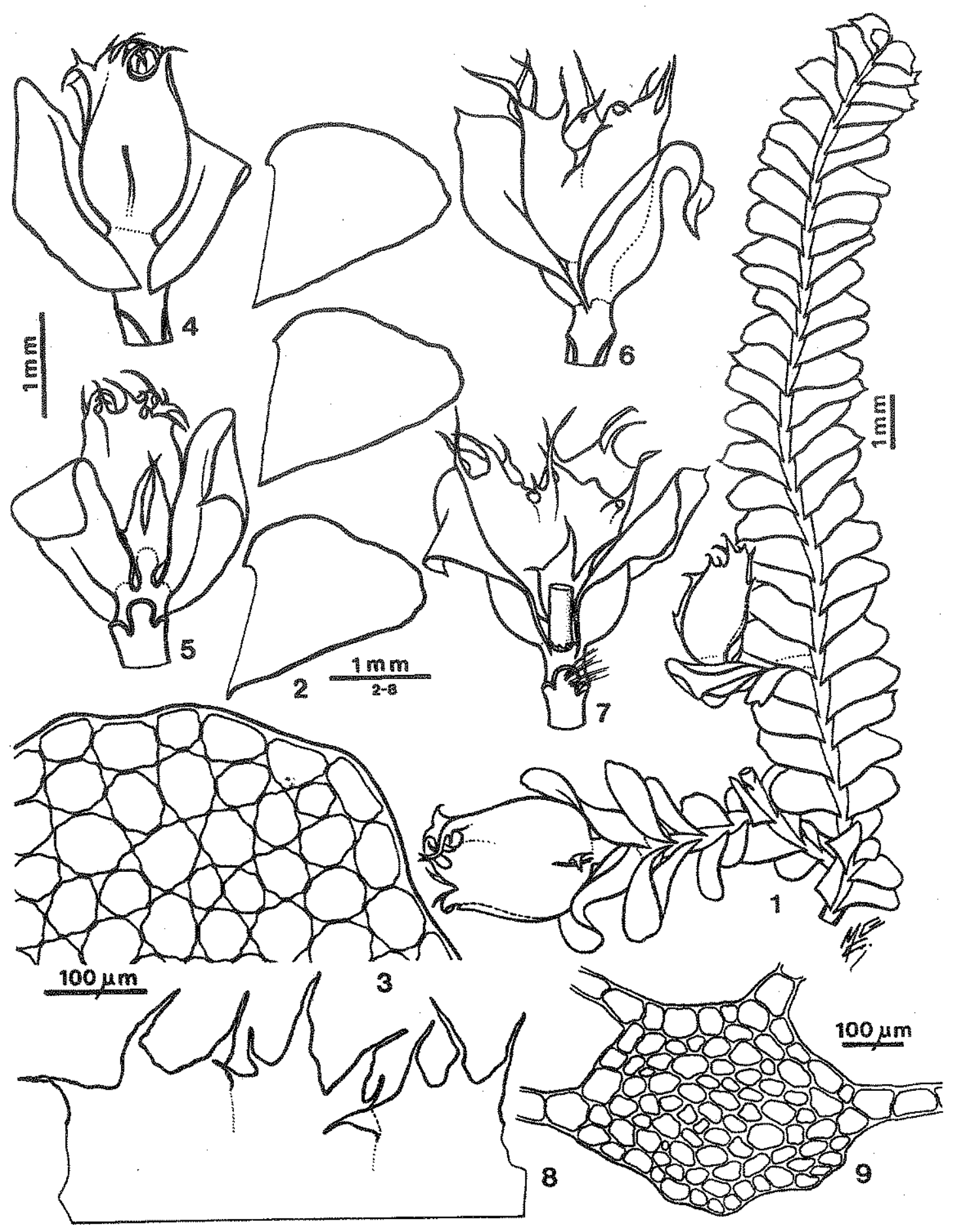

Fig. 1. Chiloscyphus magellanicus Steph. 1. Dorsal view of female plant with perianths. 2. Leaves. 3. Foliar cells. 4-7. Gynoecia: 4, 6. dorsal view of perianth with bracts, 5 . ventral view with bracteole, 7. ventral view with bracteole and innovation. 8. Distal portion of perianth. 9. Transverse section of stem. 1-5, 8-9. Chile, Virtudes I., G.H.M. TBPA-B 1905. 6-7. Chile, Ancón Sin Salida, Seno Unión, G.H.M. TBPA-B 679. 
EKeteroscyphus lobatus (Steph.) Kühnemann, Lilloa 19: 333, 1949; syn. nov. Typus: Fretum Magellanicum, Desolación I., Pto. Angosto, inter muscos et lichenes, Dusen 376 [G 000312 holotypus of Chiloscyphus lobatus Steph.(Grolle 1962:65) UPS, FH isotypi].

\section{Description}

Plants dioicous, creeping horizontally amongst other bryophytes, brown colored, in the dry condition shiny, profusely branched, leafy shoots $1,5-4 \mathrm{~mm}$ wide; branches lateral intercalary, diverging mostly at right angles from the main stem. Stem cylindric to prismatic, in t.s. $0,2-0,3 \mathrm{~mm}$ wide and high, (6)-12-14 cells wide, (7)-9-16 cells high, cortical cells $23-35 \mu \mathrm{m}$ in diam., cell walls brown, thin; medullary cells 16-35 um in diam., cell walls thickened, colourless. Dorsal stem middle line (free of leaves) at narrowest portions 2 (3) cells wide. Leaves closely imbricate, subopposite, dorsally approximate, asymmetric ovate, 1,1-1,8 $\mathrm{mm}$ long, $0,8-$ $1,2 \mathrm{~mm}$ wide; insertion oblique with short ventral arch, initially elevating from stem by the presence of large cells (c. $59 \mu \mathrm{m}$ in diam.), the limb mainly flat, dorsal border slightly recurved, ventral border plane except near the stem, where much recurved, teeth uncommon, when present, isolated, acute (1-2 cells long), l at distal basal portion or 2 at distal portion of leaf with straight sinus; middle leaf cells 54-56 $\mathrm{\mu m}$ in diam., marginal cells $35-40 \mu \mathrm{m}$ in diam., $23-40 \mu \mathrm{m}$ thick, trigones present, cuticle slightly thickened, smooth. Oil bodies unknown. Amphigastria with pronounced inverted $U$-shaped insertion, united to leaves on both sides by a 1-2 cells wide decurrent lamina, underleaf lamina cuneiform, 120-390 $\mu \mathrm{m}$ wide, 345-590 $\mathrm{m}$ high, with 2 main segments triangular, acute, elongated, slightly curved, separated by an obtuse rounded sinus, the biseriate base 4 cells long, uniseriate tip 4 cells long, l accessory long lateral curved tooth on each side, biseriate portion 2 cells long, uniseriate tip 4 cells long, additional teeth or papillae on each side also present. Rhizoids brown, abundant, borne close to amphigastria. Male plants as wide as female plants or $2-3 \mathrm{~mm}$ wide; androecia cylindric, $1,5-2 \mathrm{~mm}$ wide, with (2-3) $4-5-(7)$ pairs of perigonial bracts, borne on main stem, successive with intervals of normal leaves, or at base of lateral intercalary branches with growth continuing as a vegetative shoot, sometimes giving rise to new lateral intercalary branches from ventral bract angles; bracts with dorsal lobule; lobule liguliform, small, 1-2 dentate, involute, at base conspicuously saccate, distal lobe rounded, expanded spreading perpendicularly from shoot, ventral margin recurved.
Antheridial stalk biseriate. Perigonial bracteoles similar to amphigastria, sometimes smaller. Gynoecia on main shoot, some successive, or on short lateral intercalary branches, with subfloral innovation of lateral intercalary origin; bracts up to 3 pairs, enlarging towards apex of shoot, covering the perianth, $2,4-3,5 \mathrm{~mm}$ long, $1,2-2 \mathrm{~mm}$ wide, at base pouched, distal portion recurved, margin repand, sinuate or with small teeth; bracteoles enlarged, the lamina rounded-rectangular up to $2 \mathrm{~mm}$ high, the margins nearly entire, at apex bifid, the segments acute, short. Perianth cylindric to cupulate, $3-4,5 \mathrm{~mm}$ high, emergent, dorsal incomplete keel present or absent, lateral keels in general absent, young perianths sometimes laterally open; mouth with 3 main bisbifid portions separated by a rounded sinus, with 4 triangular laciniae, or acute curved sometimes recurved teeth, corresponding to the sides; ventral portion (when well-developed), with $2-4$ laciniae, each $0,6-0,9 \mathrm{~mm}$ long, with base c. 8 cells wide and uniseriate filament 4-10 cells long; perianth cells elongated, 47-70 $\mu \mathrm{m}$ long, $35-43 \mu \mathrm{m}$ wide, with trigones as in vegetaw tive leaves. Sporophyte unknown. No asexual reproduction present.

\section{Discussion}

This taxon was placed in the genus Heteroscyphus Schiffn. by Engel \& Schuster (1984: 400), probably because young androecia were observed close to the stem. Here it is shown, (see fig. 2.1), that the androecia are intercalary on main shoots, a detail present in the syntype of Chiloscyphus magellanicus Steph. from Smyth Channel (at $G$ ), and that when androecia originate on branches close to the stem, normal growth with vegetative leaves continues.

This species can be distinguished from $C$. durus because of its shiny brown appearance, the large cells, the narrow dorsal furrow between the subopposite leaves and the amphigastria connate on both sides to the leaves.

C. lobatus Steph., here considered a synonym of the present taxon, was placed by Grolle (1962:61) as synonym of "Leptoscyphus expansus ". Both C. lobatus Steph. and C. magellanicus Steph. are illustrated with perianths in Stephani's Icones Hepaticarum (Stephani, 1985) based on Dusen collections.

\section{Specimens examined}

CHILE: Chiloé, Aguas Buenas, road Ancud Quemli, Engel 1290 (NY as Leptoscyphus expansus). Cord. Piuchué, Villagrán 51 (VILLAGRAN) (c. per.). Pta. Tiques, Villagrán 


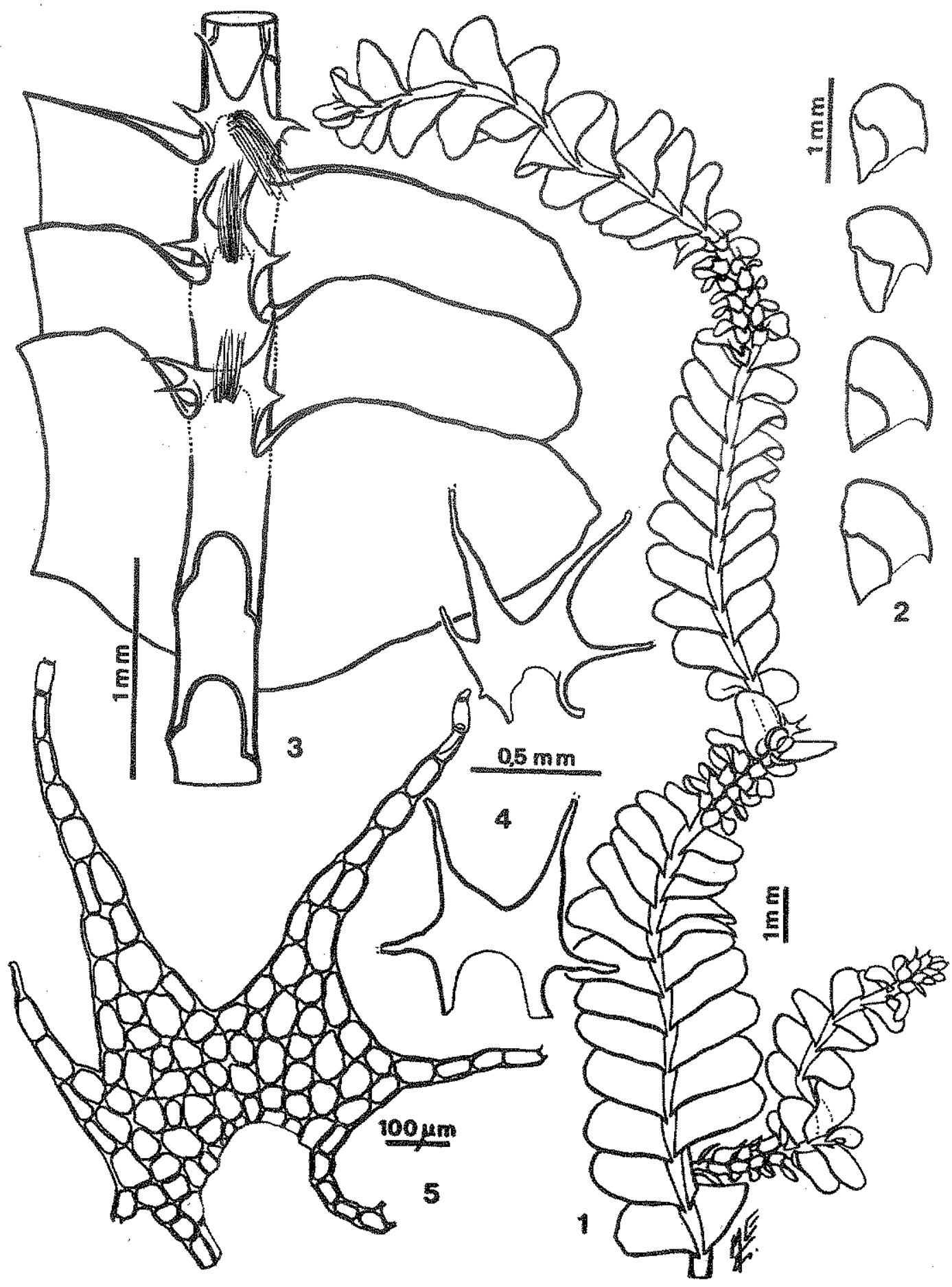

Fig. 2. Chiloscyphus magellanicus Steph. 1. Dorsal view of male plant with intercalary androecia, and androecium at branch base. 2. Perigonial bracts. 3. Ventral view of shoot. 4. Amphigastria. 5. Detail of amphigastrium. 1-5. Chile, Virtudes I., G.H.M. TBPA-B 1905 
268 p.p. (VILLAGRAN). Wellington I., Pto. Eden, Savatier 1863 (VER as Chiloscyphus pallidovirens). Baie de L' Isthme, Savatier 208 p.p. (VER as C. pallidovirens). Chatham I., on cliff, Engel 5358 A (NY). Ultima Esperanza, Ancón Sin Salida, Seno Unión, G.H.M. TBPA-B 679, 792 (c. per.). Piazzi l., Caleta Ocasión, G.H.M. TBPA-B 914 b. Virtudes I., G.H.M. THPA-B 1905 (c. per), 1907 (c. per.), id Rennel l., Eskuche 62-39 (masc. c. per.) (CTEFN). Smyth Channel (masc.) ( $G$ syntypus of $C$. magellanicus Steph.). Península Brunswick, Bahía San Nicolás, Engel $6351 B$ (NY), id, E side of B. San Nicolás, Engel 6397 (MSC as C. hookeri subsp. constantifolius J. J. Engel). Desolación I., Dusen 376 (G 000312 holotypus of Chiloscyphus lobatus Steph., UPS, isotypi). Hoste I., Hahn 451 (VER as Chiloscyphus supinus ?). Basket I. in sylvis, Darwin Sound, Spegazzini 178(x) (VER as Chiloscyphus surrepens ?). Basket I., Desolation Sound, Chilota Bay, Spegazzini 218(1) (VER as Chiloscyphus grandifolius p.p.). Cap Horn, Davis (NY hb. Hooker, syntypus of Jungermannia surrepens Hook.f. \& Taylor); id hb. Hooker p. p. (NY with C. hookeri J. J. Engel). ARGENTINA: Tierra del Fuego, Slogget Bay, in sylvis uliginosis, Spegazzini 290(1) (VER as Chiloscyphus similis, Ch. surrepens). Bahía Buen Suceso, G.H.M. 3722. Isla de los Estados (Staten I.), Spegazzini 99(3) (VER as Leioscyphus surrepens); id Spegazzini $215 p . p$. (VER as Chiloscyphus pallidovirens); id Mte. Conegliano, Spegazzini 324(1) (VER); id Mte. Richardson, Spegazzini 104(2) (VER as Chiloscyphus grandifolius?); id Bahía Franklin, Cabo San Bartolomé, G.H.M. 4557b; id Spegazzini 21(5) (VER); id Bahia Hoppner, G.H.M. 4721 (masc. c. per.); id Pto. Cook, cascada arroyo Fernández, G.H.M. 3018 p. p., 3104 b, 3143; id Pto. San Juan, Castellanos 3-I-1934 p. p. (BA 1399, 1400); id, Pto. Vancouver, G.H.M 4280. Bahía Franklin, Cabo San Bartolomé, G.H.M. 4557b.

\section{Distribution and ecology}

Chiloscyphus magellanicus Steph. is known to be present in Chile, from Chiloé, the channel islands, the Brunswick Peninsula, as far as the most southern islands of the Magellanic archipelago. In Argentina it inhabits the east southern area of Tierra del Fuego and the Isla de los Estados. It occurs in the thick bryophyte carpet that covers the ground in the Nothofagus betuloides forests, rocks, stream banks and sometimes it is submerged in bog pools of that area.

\section{ACKNOWLEDGEMENTS}

I express my gratitude to the curators of the Hepatic collections at G, H, MSC, NY, S, UPS, VER, for the loan of type and original material, to Dra. Silvia Solari for notes on the taxa treated in this paper, to Dr. Ulrich Eskuche and Dra. Carolina Villagrán for making accessible specimens collected by them, and to Dr. David Gr. Long and an anonymous reviewer for their comments on the manuscript. Field trips were financed by the CONICET of Argentina. The assistance for the preparation of this manuscript by Mrs. Marta Rubies and Mrs. Matilde Gonçalves Carralves, is also acknowledged with many thanks.

\section{BIBLIOGRAPHY}

Engel J. J. 1972. Chiloscyphus hookeri n. sp. and nomenclatural changes in the genus. Clasmatocolea. J. Hattori Bot. Lab. 36: 150-156.

- 1978. A taxonomic and phytogeographic study of Brunswick Peninsula (Strait of Magellan) Hepaticae and Anthocerotae. Fieldiana Bot. 41: 1-319.

- 1990. Studies on Geocalycaceae I. The taxonomic position of Chiloscyphus amplectens (Mitt.) Engel and Schust. together with refinements in Heteroscyphus Schiffn.J. Hattori Bot. Lab. 68: 305315.

Engel J. J. \& R. M. Schuster 1984. On overview and evaluation of the genera of Geocalycaceae subfamily Lophocoleoideae (Hepaticae). Nova Hedwigia 39: $385-463$.

Grolle R. 1962. Monographie der Lebermoosgattung Leptoscyphus Mitt. Nova Acta Leop. 25(161): 1-143.

Stephani F. 1985. Icones Hepaticarum. Microfiche. Leiden: IDC.

Recibido: 12-V-1999 Aceptado: 2-XI-1999 